\title{
Building Resilience: The Gendered Effect of Climate Change on Food Security and Sovereignty in Kakamega-Kenya
}

\author{
Pauline Liru * and Lindy Heinecken * (D) \\ Department of Sociology and Social Anthropology, Stellenbosch University, Stellenbosch 7602, South Africa \\ * Correspondence: Pauline.liru@uonbi.ac.ke (P.L.); Lindy@sun.ac.za (L.H.)
}

check for updates

Citation: Liru, P.; Heinecken, L. Building Resilience: The Gendered Effect of Climate Change on Food Security and Sovereignty in Kakamega-Kenya. Sustainability 2021, 13, 3751. https://doi.org/10.3390/ su13073751

Academic Editor: Gideon Baffoe

Received: 19 January 2021

Accepted: 24 February 2021

Published: 27 March 2021

Publisher's Note: MDPI stays neutral with regard to jurisdictional claims in published maps and institutional affiliations.

\begin{abstract}
Climate change is a global threat, affecting the food security and food sovereignty of many depending on agriculture for their livelihoods. This is even more pronounced in Kenya, given their over-reliance on rain-fed crops and the frequency of floods and droughts in the country. Through qualitative interviews, this study set out to establish how climate change not only affects the food security, production and consumption of rural women farmers in Kakamega County, Kenya, but their response to climate shocks. Using resilience theory as a lens, we established that women use different pathways to mitigate the effects of climate change on their livelihoods. The study found that initially women adopt coping strategies that are reactive and not sustainable, but soon adapted their farming strategies, using their indigenous knowledge to exercise some control over both their food security and food sovereignty. Besides this, they use their human and social capital to expand their networks of support. By linking up to other organizations and gaining access to government support, they are able to challenge patriarchal relations that perpetuate poverty and inequality and bring about more transformative and sustainable responses to climate change.
\end{abstract}

Keywords: climate change; food security; food sovereignty; food production; resilience strategies; gender

\section{Introduction}

Climate change is one of the most severe global issues affecting the planet in the 21st century, affecting the livelihoods of men and women across the world [1-4]. Africa is most vulnerable to climate change due to the over-reliance on rain-fed agriculture for crop production [5-7]. Kenya, in particular, has livelihood systems that are highly dependent on natural resources [8,9]. Rain-fed agriculture is the dominant source of livelihood income and the major means of food production for the majority of the rural poor [10]. Over $80 \%$ of the Kenyan population live in rural areas and depend directly or indirectly on agriculture for their survival [11]. This makes the country highly vulnerable to the effects of climate change and weather variability that give rise to droughts, floods and other natural disasters.

In this regard, Kenya is ranked as the 31st most vulnerable country and 37th least prepared to cope with climate change and its effects in the Notre Dame Global Adaptation Index (ND-GAIN) vulnerability index3 (2017). The country is also considered first among East Africa's most disaster-prone countries [12]. Women play a major role in rural agriculture in Kenya, providing between 42 and 65\% of the agricultural labor force [13]. In Kakamega County in Kenya, the focus of this study, $61 \%$ of the inhabitants rely on crop and livestock production for their livelihood [14] and this production accounts for $65 \%$ of the total earning of the county [14]. The county is the food basket of Kenya, which produces rain-fed crops such as maize, beans, sweet potatoes, cassava, bananas, sorghum, finder millet, local vegetables, rice, tea, sugarcane and horticultural crops [15].

Similar to the rest of Kenya, the county has experienced climate change in terms of rising temperatures, irregular rainfall, droughts and floods [16]. Rural women, who constitute the majority of small-scale farmers, are hard hit by climate change, as they depend 
heavily on rain-fed agriculture for food production and consumption [17]. Furthermore, studies show that women suffer from the effects of climate change more than men, due to gender inequalities that limit their access to assets such as land, livestock, labor, education, financial services and technology [18]. While this has a profound effect on food security, women have found ways to adapt to climate change. As this study shows, women are not passive victims of climate change $[19,20]$ and have adopted various strategies to mitigate the effects of climate change on their livelihoods [21-23].

By focusing on Kakamega County, Kenya, we explain how women adapt to climate change by changing what they produce and consume and the strategies they adopt to enhance their food security and sovereignty. Through qualitative interviews with women residing in the area, this study shows that women adopt various resilience strategies to mitigate the effect of climate change. While there have been several studies on gender-differentiated impacts of climate change, especially in the African context [19,24], some $[13,17,25]$ tend to portray women as victims who are more vulnerable than men [19]. Comparatively few studies focus on climate change adaptation among women [19]. To fill this void, the aim of this study is to show how women are able to use their agency to develop their resilience to climate shocks and exercise some greater degree of control over their food security and sovereignty. The claim is made that while women have found ways to absorb and adapt to the effects of climate change on their livelihoods, that their resilience to implement transformative strategies is hampered by gender inequality and patriarchy embedded within society.

\section{Climate Change and Resilience-Building}

Climate change has a profound effect on food security and sovereignty. Changes in weather patterns affect the availability of food, access to food, utilization of food, the stability of food supply and nutrition of people. All these elements of food security are gendered due to women's role in agriculture, access to resources, and the differentiated gender roles and responsibilities expected of them [26,27]. Despite the past gender and climate adaptation discourses that predominantly portray women as victims of climate change and subjects more vulnerable than men, recent studies tend to challenge this generalization $[19,20]$. Studies show that rural small-scale women farmers adopt different pathways to build resilience when faced with climate-related shocks that affect their livelihood [28,29].

Resilience-building refers to the ability of people to cope with the stresses and shocks of climate change by anticipating, preparing for, responding to and recovering from them [30]. The literature on resilience and climate change indicates that there are different ways to build resilience [31,32]. There are three different pathways that farmers use, namely developing their absorptive coping capacity, adaptive capacity and transformative capacity [31] Absorptive resilience refers to the ability of individuals to cope with the impacts of climate change on their livelihoods within their immediate means [33]. This is reactive and often short-lived, especially if subjected to successive shocks. Consequently, individuals need to develop their adaptive capacity, which refers to their ability to manage future risks and bounce back when shocks occur [21]. Last is the need to develop transformative resilience in terms of access to different resources, as well as change certain practices that enable them to move beyond the vulnerability threshold [33].

Using this as a theoretical lens, one can analyze the various stages that the rural farmers use to mitigate the effects of climate change on their food (in)security and sovereignty. In terms of absorptive capacity, one of the first responses to climate change is to change patterns of consumption. According to Johnson, Kovarik, Meinzen-Dick and Njuki [34], the main strategies that women adopt to ensure some stability in food supply is to purchase food if they have the means, to reduce consumption or to consume different foods that are easily accessible and to share resources or to sell existing assets. Although these are common coping strategies, they are not sustainable since droughts are typically associated 
with food shortages and price increases that heighten food insecurity. Merely absorbing the shocks deepens poverty as vital assets are often disposed of in order to survive.

To mitigate the effects of climate change, famers need to adapt their agricultural practices by drawing on all their available resources. The degree to which farmers are able to adapt to the effects of climate change depends on their access to various capitals and the resources linked to them [35-37]. These include the capitals that households and communities draw on to cope with the impacts on their livelihoods [38] and include access to natural, financial, physical, human and social capital $[39,40]$ to mitigate vulnerability [41]. Typically, women have less access to assets that stem from these capitals, like land, finances, technology, education and networks, which undermines their adaptive capacity [42]. As such, women tend to rely on and use their immediate human capital, in terms of physical labor and indigenous knowledge, as well as social capital to adapt to the effects of climate change on their livelihoods. Using these capitals, women typically resort to planting different crops that are drought-resistant and using their indigenous knowledge of weather patterns to know what kinds and crops to plant and when.

Where women are able to use their human and social capital to link up with community organizations, non-governmental organizations (NGOs) and state institutions, they have been able to not only access different capitals, but transform their livelihood strategies in the face of climate change. In fact, the more connected in terms of their bonding, bridging and linking social capital, the greater the access to different forms of capitals and ability to change, or diversify their livelihood strategies. To be transformative, women's voices need to be heard, respected and integrated into existing systems. For women, this implies challenging patriarchal and social relations that affect their equal access to different forms of capitals, power and influence in decision-making. When this occurs, only then are women able to move beyond the vulnerability threshold that affects their ability to mitigate climate-related shocks on their livelihoods.

\section{Methodology}

This study was informed by the broader literature on climate change. The theoretical underpinning of the study was the sustainable livelihoods framework, resilience theory and feminist theory. The aim was to establish what assets women draw on and what strategies they adopt to cope, adapt and build resilience in response to the effects of climate change. Furthermore, we investigated how gender inequality and patriarchy affects women's ability to implement transformative approaches to climate change. The study did not set out to test a particular theory, but to understand how resilience strategies are affected by gender, thereby contributing to a developing body of literature in the field.

In terms of the study design, Kakamega Country in Kenya was selected as the location, given the profound impact of climate change on rural agriculture in the region, and particularly on women farmers as producers. The study took place between September 2017 and January 2018, where a total of 138 participants from five different sub-counties in Kakamega County were interviewed (Figure 1). The study included 75 women and 63 men. Using a qualitative research design, the aim was to explore the lived experiences of poor rural women practicing small-scale agriculture and how they were coping with the effects of climate change on their livelihoods. The data collection methods varied, in order to ensure the credibility, dependability, transferability and conformability of the data.

Qualitative data collection methods used included life histories of women to elicit individual experiences of climate change over time; focus group discussions to bring out the views of how they were coping and adapting; and key informant interviews to capture the ideas of knowledgeable stakeholders in the sector and their attitudes towards women farmers. Fourteen focus group discussions (FGDs) were conducted, with three different FGDs per sub-county, one having mixed male and female participants, another with male participants only and another with female participants only. Women-only focus groups ensured the full participation of women in the discussions, as men tend to dominate or shape their ideas [43]. The FGDs took place in four sub-counties (Matungu, Lugari, 
Mumias west and Malava), to ensure that a diversity of views were captured. In addition, sixteen key informant interviews and ten life histories were conducted to capture the lived experiences of women farmers. Participant observation was also conducted during the fieldwork though assisting the women farmers in their daily tasks and taking field notes to capture their everyday experiences and interactions.

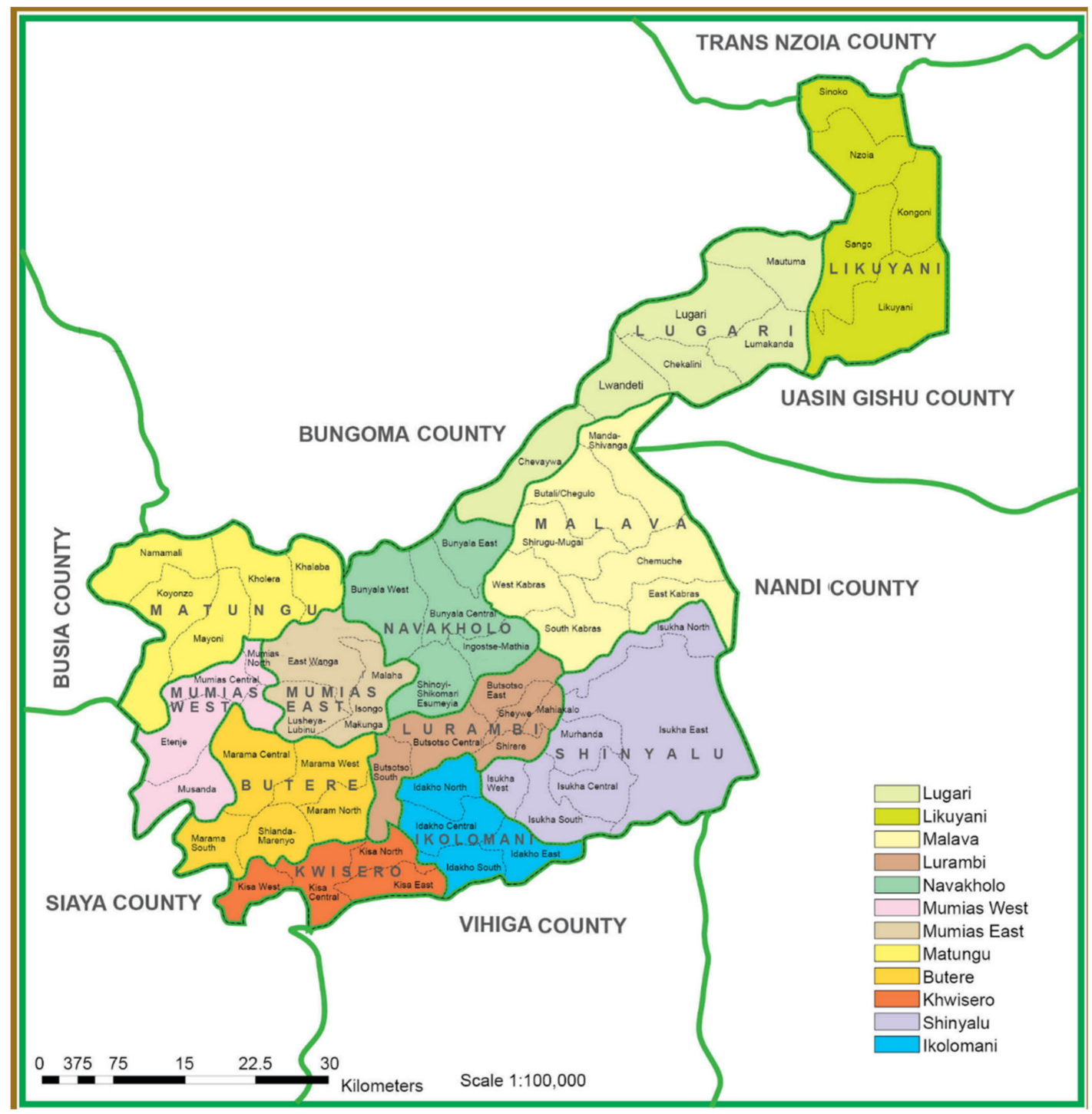

Figure 1. Map of Kakamega County, Kenya.

Thematic analysis was used to identify the various strategies women use to mitigate the effect of climate change on their food security and sovereignty and how they sought to build their resilience to climate-related shocks. All the interviews were audio-recorded and transcribed verbatim in the local language (Luhya). The transcripts were then translated and back-translated to avoid loss of meaning, after which the finalized transcripts were coded based on themes and sub themes into computer-aided qualitative data analysis software NVIVO 11. After coding, the information was grouped into themes related to the research objectives.

The ethical protocols as per the policy for responsible research were adhered to in terms of confidentiality, anonymity and principle of doing no harm to human subjects. The research questions were: (1) How do women cope with the influence of climate change on their livelihoods? (2) What capitals do they draw on to adapt and build resilience? 


\section{Study Findings}

The findings of this study show that the women farmers in Kakamega County have adopted various resilience strategies to mitigate the effects of climate change on food security and sovereignty, by drawing on the various assets at their disposal. As the findings show, their capacity to mitigate the effects of climate change are influenced by the patriarchal culture embodied within society.

\subsection{Experiences of Women in Adapting to Climate Change}

In this section, we report on the lived experiences of women in Kakamega County in terms of (1) how climate changes affected food security and consumption; (2) how women cope with food security at household level; (3) how they adapt their agricultural and livelihood practices to exercise some form of control over their food security and sovereignty; and lastly (4) how they use their human and social capital to adopt more transformative approaches to food security and sovereignty.

\subsection{Effect of Climate Change on Food Security}

The study documented far-reaching effects of climate change on crop production and women's livelihoods. The effects of climate change on food production were reported at various levels. The women described how frequent droughts often led to delayed planting and contributed to subsequent crop failure due to this surpassing the ideal planting period. Besides this, they spoke of how floods swept away farm crops and how hailstones destroyed crops leading to low yields. This affected the production of staple food crops such as maize and beans, which have both a direct and indirect impact on women farmers expected to process, cook and serve food for the family. The excerpt below points to the effects of climate on crop production.

For me, the heavy downpour has really affected my life, you know here most people do farming along the plains next to the river, and the entire area I farm is usually washed away by the river during heavy downpours. I have been affected in the last three years and have not had any harvest from my farm. (Women Farmer FGD Lugari)

Climate changes not only affects food production, but post-harvest processing and storage. The participants reported post-harvest grain loss due to bad weather. For instance, when there is inadequate sunlight, grains cannot dry out sufficiently to be stored, and they become moldy and end up being discarded. Not only crop but livestock production is also affected by climate change. Participants spoke of how during droughts, livestock typically become undernourished and die, but are similarly affected by wide-scale flooding. For example, in Eastern Africa, Rift Valley Fever outbreaks are often associated with El Nino, while in other parts of Africa, Rift Valley Feaver RVF outbreaks have been shown to occur after extreme precipitation events [44]. Another livestock disease associated with flooding is leptospirosis and foot rot. These diseases result in both livestock morbidity and mortality (Paul, Weinthal \& Bellemare, 2016). Participants explained that in Kakamega County, foot and mouth disease affects mainly the smaller animals kept by women, less so cattle which is affected more by RVF. During a key informant interview, a veterinary officer reported:

Here we don't have large herds of livestock due to limited land, but we usually lose even the little we have to two main reasons: Rift Valley Fever and foot and mouth rot. These diseases only occur during the rainy seasons and are associated with stagnant water and affect the production of both milk and meat as well as livestock death. (Veterinary officer, Lurambi)

The above is just a brief snapshot of the impact of climate change on food production, which affects food security and consumption. For example, livestock diseases not only lead to livestock death, but affect the reproduction and immunity of animals. This in turn impacts on the production of milk, availability of meat for consumption and the income of farmers [45]. Participants reported how the climate-related diseases drive up the costs of 
caring and treating animals affected, but also of how they have come to mitigate the effects of climate change on their livelihoods.

\subsection{Food Insecurity and Absorptive Coping Strategies}

The most immediate effect of climate change is on food (in)security. According to Johnson et al. (2016), the main strategies that women adopt to cope with food shortages is to purchase food if they have the means, to reduce consumption or to consume different foods that are easily accessible. In a study in Kenya on the effects of climate change on food security, it was found that $63 \%$ of respondents tended to resort to purchasing food in response to climate-related shocks [46]. Although this is a common coping mechanism, it comes with challenges since droughts cause food shortages and price increases that heighten food insecurity. Again, this tends to affect women more than men given their limited access to financial capital.

What became clear from the conversations with participants were the gendered effects that a decline in food security evokes. During periods of food shortages, women tend to feed the children first, or skip meals for the sake of their families. As other studies have shown, such behavior affects women's health negatively since they become weaker and malnourished and even more so if they are nursing [38,47] A female FGD participant in Malava said:

Here since it is the role of women to feed the family, most women reduce their food consumption during food scarcity and some skip meals to spare food for the children. This affects the health of mothers, especially lactating or expecting women who need special dietary requirements. (Female FGD participant, Malava)

While food scarcity and consumption affects both men and women's health, the impact is more severe for women. For example, during periods of drought women have to travel even further to fetch water and firewood as part of their household tasks. As most rural farmers depend on their physical labor for income and their livelihoods, food insecurity affects not only the ability to work productively, but the time available to perform both productive and reproductive work. Both spheres compromise the quality and quantity of work and care women provide. This came up in the conversations with women in terms of their time available to perform the different tasks expected of them. Another coping strategy is to take up employment outside the family. A women representative in a key informant interview reported:

During extremely dry periods, we women can do anything to get money for the family. Some women offer household/domestic labor to better families for as low as Kshs 100 per day and most of them struggle to access such jobs because that could be the only way to survive. (Female participant, Lurambi)

Having to work long hours for little money far away from their homes means they spend less time on their domestic roles such as taking care of the children, cooking and handling other family duties. The inability to handle family/household chores due to leaving early and coming back late at night is reported to have aggravated gender-based violence (GBV). In a focus group discussion, a female participant reported:

During drought we as women have so many duties, we look for income-generating activities far away from home and at times we have to get basic household needs such as water from afar, yet during that time most women are beaten by their husbands and sent away because their husbands feel that they have not performed their roles. Such incidents are very common during dry periods or scarcity. (Female FGD participant, Matungu)

Apart from exploitation and gender-based violence, women tend to sell their household belongings to feed their families during drought-stricken periods. Since most rural women lack cash, they pawn or sell their property such as kitchenware, poultry or any asset that belongs to them. The act of disposing assets can only help women to cope with their immediate circumstances, which often leaves them more vulnerable to the ravaging effects of prolonged shocks. 
Other coping strategies are to draw more heavily on natural resources, such as charcoal burning and brick making. However, these activities have a detrimental effect on the environment where trees are cut for both charcoal and fuel. These products are sold on the markets in the nearby urban centers such as Malava, Chavakali and Kakamega as explained by a female participant:

When life becomes very difficult and I have no food, I just get to the forest and cut some wood, dry them and take to the market. Another option is to burn charcoal and sell in the nearby center to get cash. (Female FGD participant, Lugari)

Cutting down trees increases the effects of climate change due to droughts and flooding as it reduces water catchment and interferes with rain patterns. In addition, if trees are not replenished, the soils remain bare and subject to soil erosion as well as windstorms. Brick making is also a negative coping strategy since clearing the land and tilling the soil leaves behind bare land and holes that develop into gullies, causing erosion. What the above indicates is that these absorptive coping strategies are not sustainable, increasing poverty and the vulnerability of households.

\subsection{Adaptive Strategies to Improve Food Security and Sovereignty}

Having been subject to prolonged climate shocks, women farmers explained how they resorted to different strategies to enhance their food security and sovereignty. Such strategies include intercropping and crop diversification to offset the effects of floods and droughts on different plant species. Intercropping is the practice of planting different kinds of crops on the same piece of land [48]. This multiple cropping system encompasses the practice of planting two or more species of crops simultaneously within the same field during a specific growing season. The practice has been found to increase crop yields due to a higher growth rate, weed reduction and reduction of pests and diseases [48]. It is also an effective way to minimize resource use and maximize output, since farm operations cover more than one crop simultaneously. In addition, intercropping increases soil fertility, especially leguminous crops due to their nitrogen-fixing capacity.

Apart from intercropping, crop diversification is another strategy that women in Kakamega use. Crop diversification is the practice of cultivating more than one variety of crops belonging to the same or different species in a given area. This is a way to enhance resilient agricultural systems, particularly in areas affected by climate changes and in communities mostly reliant on rain-fed systems of agriculture. Although the Kakamega area is known for maize production, women farmers explained how they have come to plant other crops such as beans, sweet potatoes, wild vegetables, cowpeas, tomatoes, pineapple and other horticultural crops which are affected differently when subject to climate-related shocks. There is also an increase in the farming of cassava, which is drought-resistant. In a key informant interview, the crop production officer reported:

What has helped women cope so much with the effects of climate change in this area is that they are able to diversify crops; they plant several varieties of crops unlike men who only do sugarcane. You will find that for women, when beans fail, they have maize, if maize does not do well, they have cowpeas, cassava, yams, sweet potatoes, local wild vegetables, watermelon and pineapple among many other crops and so they always have options. (Crop Production Officer)

Diversification is a strategy to ensure that they have access to a variety of foods, both for household consumption and for sale at the markets. In addition, women have increasingly come to plant indigenous crops or traditional vegetables, which are both drought-resistant and culturally accepted [21]. However, the extent to which women are able to adapt and diversity their crops is influenced by their access to various assets.

Studies show that the more assets people can draw on, the more they are able to cushion their livelihoods from climate shocks [34,49]. In Kenya, women have limited access to assets necessary for food production such as land. In fact, only 1-5\% of land titles in Kenya belong to women [50]. The limited access to land affects access to a range 
of other resources, such as financial security, food, water and shelter, especially for those who depend on land for their survival [18]. However, within these material and cultural confines, women have found ways to expand and grow their assets. In a life history interview with a female farmer, she narrated how chicken production helped her to cope with the effects of climate change. She explained:

I started with 5 chicks and now I have 90 local breeds. During dry periods when food is limited, I just sell one chicken and am able to buy sugar, cooking oil, cooking flour, salt and other things that I need for household consumption. (Elderly Female participant, Mumias)

According to the livestock production officer, women depend on chickens because they require little capital investment and it is encouraged culturally as a female source of livelihood. The men also encourage women to rear chickens, because it is a special meal. An excerpt from a livestock production officer said:

You know chicken is a delicacy in this area, when one has a visitor, the special meal for welcoming visitors here is chicken, in addition, you will find that the men perceive chicken as a woman's livestock and are happy when a woman slaughters chickens because they know that certain special parts — the gizzard (imondo)—is preserved for them. (Male livestock productions officer)

The fact that women have some control over certain crops and livestock gives them agency and this is enhanced by their indigenous knowledge of farming. The women interviewed spoke of how they have come to predict weather and climate patterns, in order for them to decide what crops to plant. They spoke of how they watch the movements of certain birds and insects to foretell the onset of rainy seasons, to prepare for what is coming. Based on this, they know when to plant and if necessary, to plant more drought-resistant crops such as sorghum and cassava. These plants are known to endure and can overcome the effects of climate change, unlike maize. A woman farmer said:

When we predict less rain or a prolonged dry period, we decide to plant drought-resistant crops such as cassava and some variety of sorghum (the red one); these are able to do well even during the short rains and can also overcome mild droughts. (Female FGD, Matungu)

They spoke of how they have learnt to preserve indigenous seeds and grains that survive drought and flood conditions and to preserve these for the future, demonstrating their ability to exercise some form of food sovereignty. Beyond this, the women in KaKamega relayed how they make their own natural pesticides and herbicides to control climate-induced pests and diseases. This indigenous knowledge empowers women, even more so where they link up in women's groups at the community level.

\subsection{Transformative Resilience Strategies}

Possibly the greatest asset that women have is the resilience among themselves. In rural communities, knowledge sharing among women is common, especially where they come together in groups to share critical information on adaptation and coping mechanisms [18]. In Kakamega Country, almost every woman belongs to some or other women's social group. These include self-help groups or women's groups that typically assist women to secure loans, build trust, access training services and link women to formal institutions which they can rarely access individually. These groups provide social support to women during tragedies and climate-related disasters, provide financial support during times of scarcity and help members start small business ventures. In a narrative with female farmers in Lubao, one reported:

As women we have survived on groups ... I belong to the Amani women group. The group has helped me to access loans as a member during times of scarcity, it has uplifted me financially, provided me with different forms of training and has often linked us to other farmer organizations and has been very instrumental in providing us with support during calamity. (Female Farmer, Malava) 
Besides these informal community social groups, the church plays an important role during times of difficulty. Church members typically pull resources together in the form of offerings, with the resources redistributed to the poor and needy during dry seasons. Besides, the churches are important in building the bridging capital of women as women from different social classes link up and support each other through the church. In a key informant interview with a religious leader, he reported:

This church called Friends Church is a real friend to the community, we are not only church members but also friends, we support one another socially, spiritually and financially and when anyone becomes sick, we visit them and also provide basic needs to the destitute. (Male Religious Leader, Lugari)

Apart from church-based groups, women farmer groups and self-help groups in Kakamega empower women by helping them to secure loans, gain access to training services and link women to formal institutions that help members start small business ventures. The groups enable women to gain access to land, finances or equipment that enable them to diversify their livelihood strategies.

The women's groups also link women farmers to organizations that promote agriculture, such as the One Acre Fund, which provides women with quality seeds and farm inputs and trains small-scale women farmers in groups to attain maximum yields. The organization provides tree seeds to women farmers as a way to help mitigate the effects of climate change. Through links with such groups, rural women farmers have been able to grow crops and attain good harvests, despite the constraints. This is congruent with the literature that finds that linking farmers to local organizations can be instrumental in building resilience to climate change (Olivier, 2015, Oliver \& Heinecken 2017). Women's groups also link farmers to institutions that provide technical climate information, such as the Kenya Agricultural Research Institute (KARI), which provides information on both climate and how to adapt to changes in weather patterns.

This pertained not only to disseminating information about the effects of climate change. In the context of Kakamega, women farmers through their community organizations were linked to financial institutions such as Kenya Women Finance Trust, K-Rep Bank in Malava and women-supported Community Based Organization CBOs. These organizations provided women with loans which enabled them to purchase land and acquire the necessary implements to improve their farming methods. Financial institutions also offer women insurance for major life events, savings and credit facilities, social assistance facilities and access to public goods and services. What this demonstrates is the importance of social capital to enable women to gain access to different forms of capital in order for them to diversify their livelihood strategies and reduce the vulnerabilities created by climate change.

What one sees is that these community-based groups, farmer's groups, community networks, credit groups, savings and credit societies, cooperatives and village councils are able to develop the capacity of women to transform their livelihood strategies [51]. In cases of prolonged shocks, these networks and their links to government are able to build the transformative resilience necessary to mitigate the vulnerabilities that climate change evokes. They facilitate access to capitals normally denied; giving women some degree of power and control, enabling their voices to be heard, respected and integrated into the existing system. In patriarchal societies such as Kenya, this has enabled women to challenge existing social relations and transform their agricultural practices. In so doing, they have been able to exercise greater control over both their food security and sovereignty.

\section{Conclusions}

This study confirmed that changes in weather patterns, including temperature changes, variability in precipitation and prolonged dry periods, are the major climate changes affecting the livelihoods of women living in the Western Kenyan county of Kakamega. The effects are real and influenced by extreme climatic events, including floods and droughts and the related natural disasters that affect crops and livestock. The effects are most 
profound on women, due to their reliance on the natural environment for survival and limitations placed on their ability to access different capitals due to patriarchal societal values. Women farmers typically lack the natural, financial and physical capital of men to augment their capacity to adapt, but as this study has shown, they do not lack agency. They use and have come to expand both their human and social capital to mitigate the effects of climate change on their livelihoods.

Using resilience theory as an analytical framework, the different resilience coping strategies of women were uncovered. All the three forms of resilience essential for livelihood adaptation were evident, which served to not only alleviate the impact of climate change on their livelihoods, but enhance the food security and sovereignty of the rural women farmers. At first, women responded to climate change through adopting various coping strategies to deal with food insecurity. However, these were merely absorptive coping strategies where they utilized their existing assets to survive, which were not sustainable and were typically over-reliant on the natural environment. These strategies did little to improve the food security or food sovereignty of women and increased their vulnerability to further climate-related shocks. However, using their indigenous knowledge of weather patterns and farming, the women incrementally adapted to the effects of climate change.

The adaptive strategies were more proactive, where the women used intentional practices to cope with known shocks and stresses. Adaptive capacity emphasizes flexibility, and the capacity of a system or an individual to make incremental changes in terms of continuous adjustment, learning, and innovation. In terms of adaptive strategies, through the various women's groups and community organizations, women in Kakamega share knowledge and decide on what climate-resilient crops to plant based on their shared knowledge and prediction of weather patterns, as a kind of insurance against unpredictable climatic conditions. For example, they have moved towards a greater integration of crops with livestock production to enhance productivity, efficiency and sustainability. The ability to share financial and technological knowledge and other forms of human capital influences the effectiveness of this adaptation strategy. In the process, women become both the producers and practitioners of indigenous climate knowledge. While this did improve their food security and sovereignty, these practices remained over-reliant on natural resources and were influenced by broader patriarchal relations that affected their access to various capitals.

Transformative strategies of building resilience were observed among women farmers in Kakamega, which involved using their agency to make intentional changes or arrangements to halt or lessen the risk factors of climate change, including their vulnerability, poverty and inequality that pre-dispose them to climate-related shocks. Here, women's social capital was key to building the resilience of rural women, who used their social capital to gain access to financial, natural and physical capital that enabled them to collectively deal with the impact of climate change. Women's groups linked women farmers to institutions that provide technical climate information and how to adapt to changes in weather patterns. While institutions may provide advice on climate change and how to act, the literature has proved that there are different levels of uptake. An important finding of this study was just how important the links between governmental institutions, civil organizations and communities are to enable people to cope but also challenge gender inequality and patriarchal value systems.

In Kakamega, at the communal level women are already taking up roles traditionally filled by men and are challenging the patriarchal societal rules that deny them access to various capitals. In a push towards financial inclusion, financial institutions such as Faulu bank and Kenya Women Microfinance Bank are now providing loans to women without discrimination. The county government has also initiated a shelter program focused on poor, older widows [14]. There are national programs to address gender inequality and to include gender in all decision-making processes. Such examples include the women enterprise fund, uwezo fund and the legislation of the two-thirds gender rule. This is 
imperative, as it is clear that existing patriarchal relations and gender inequality undermine both men and women's food sovereignty, food security and sustainable food production in Kenya. What this study clearly illustrates is that gender matters, and that it is vital to empower women and integrate them into decision-making processes, given their key role as producers of food and keepers of indigenous knowledge.

Author Contributions: Conceptualization, P.L. and L.H.; methodology, P.L.; software, P.L.; validation, L.H.; formal analysis, P.L. and L.H.; investigation, P.L.; writing-original draft, P.L.; writing-review and editing, L.H.; visualization, L.H. Both authors have read and agreed to the published version of the manuscript.

Funding: This research received no external funding.

Institutional Review Board Statement: The study was conducted according to the guidelines of the Declaration of Helsinki, and approved by the Institutional Review Board (or Ethics Committee) of Stellenbosch University.

Informed Consent Statement: Informed consent was obtained from all subjects involved in the study. The participants were duly informed and consented to publication of the study findings.

Conflicts of Interest: The authors declare no conflict of interest.

\section{References}

1. Swai, O.W.; Mbwambo, J.S.; Magayane, F.T. Gender and perception on climate change in Bahi and Kondoa Districts, Dodoma Region, Tanzania. J. Afr. Stud. Dev. 2012, 4, 218-231.

2. Thakur, S.B.; Bajagain, A. Impacts of Climate Change on Livelihood and its Adaptation Needs. J. Agric. Environ. 2019, $20,173-185$. [CrossRef]

3. Campbell, B.M. Reducing risks to food security from climate change. Glob. Food Sec. 2016, 21, 24-37. [CrossRef]

4. Awojobi, O. The Impacts of Climate Change in Africa: A review of the Scientific Literature. J. Int. Acad. Res. Multidiscip. Impact Factor 2017, 5, 1-52.

5. Niang, I.; Ruppel, O.C.; Abdrabo, M.; Ama, E.; Lennard, C.; Padgham, J.; Urquhart, P.; Adelekan, I.O.; Archibald, S.; Balinga, M.; et al. Africa. In Climate Change 2014: Impacts, Adaptation and Vulnerability-Contributions of the Working Group II to the Fifth Assessment Report of the Intergovernmental Panel on Climate Change; Cambridge University Press: Cambridge, UK; New York, NY, USA, 2014; pp. 1199-1265.

6. Serdeczny, O.; Adams, S.; Baarsch, F.; Coumou, D.; Robinson, A.; Hare, W.; Schaeffer, M.; Perrette, M.; Reinhardt, J. Climate change impacts in Sub-Saharan Africa: From physical changes to their social repercussions. Reg. Enviton. Chang. 2017, 17, 1585-1600. [CrossRef]

7. Thornton, P.K.; Herrero, M. Adapting to climate change in the mixed crop and livestock farming systems in sub-Saharan Africa. Nat. Clim. Chang. 2015, 5, 830-836. [CrossRef]

8. Ayugi, B.O.; Tan, G. Recent trends of surface air temperatures over Kenya from 1971 to 2010. Meteorol. Atmos. Phys. 2019, 131, 1401-1413. [CrossRef]

9. Nyanjom, O. Remarginalising Kenyan Pastoralists: The Hidden curse of national growth and development. Afr. Study Monogr. Suppl. Issue 2014, 50, 43-72.

10. Huho, J.M.; Mugalavai, E.M. The Effects of Droughts on Food Security in Kenya. Int. J. Clim. Chang. Impacts Responses 2010, 2, 61-72. [CrossRef]

11. Republic of Kenya. Climate Change Profile; Ministry of Environment and Forestry: Nairobi, Kenya, 2018.

12. Alston, M. Gender mainstreaming and climate change. Women's Stud. Int. Forum 2013, 47, 287-294. [CrossRef]

13. County Government of Kakamega. Kakamega County Intergrated Development Plan 2018-2022; County Government of Kakamega: Kakamega, Kenya, 2018.

14. Ondiba, H.A.; Matsui, K. Social attributes and factors influencing entrepreneurial behaviors among rural women in Kakamega County, Kenya. J. Glob. Entrep. Res. 2019, 9, 1-10. [CrossRef]

15. CIAT-International Centre for Tropical Agriculture. Climate Risk Profile Economic Review of Agriculture Intergovernmental Panel on Climate Change Society for International Development Kakamega; CIAT-International Centre for Tropical Agriculture: Nairobi, Kenya, 2018.

16. Hannan, C. An overview of women, gender and climate change issues. Education International's World Conference "On the Move for Equality"; Bangkok, Thailand, 2011, pp. 20-23. Available online: http://download.ei-ie.org/Docs/WebDepot/21.2.6\%20women\% 20and\%20climate\%20-\%20presentation.pdf (accessed on 17 February 2021).

17. Arora-Jonsson, S. Virtue and vulnerability: Discourses on women, gender and climate change. Glob. Environ. Chang. 2011, 21, 744-751. [CrossRef] 
18. Gonda, N. Climate Change, 'Technology' and Gender: 'Adapting Women' to Climate Change with Cooking Stoves and Water Reservoirs Climate Change, Gender: 'Adapting Women' to Climate Change with Cooking Stoves and Water. Gend. Technol. Dev. 2017, 20, 149-168. [CrossRef]

19. Nellemann, C.; Verma, R.; Hislop, L. Women at the Frontline of Climate Change: Gender Risks \& Hopes; United Nations Environment Programme: Nairobi, Kenya, 2011; p. 66.

20. Hoddinott, J.; Kinsey, B. Adult Health in the Time of Drought; International Food Policy Research Institute: Washington, DC, USA, 2000; Volume 97.

21. Fajarwati, A.; Tyas, E.; Mei, W.; Hasanati, S.; Meilyana, I. The productive and reproductive activities of women as form of adaptation and post-disaster livelihood strategies in Huntap Kuwang and Huntap Plosokerep. Procedia Soc. Behav. Sci. 2016, 227, 370-377. [CrossRef]

22. Denton, F. Climate change vulnerability, impacts, and adaptation: Why does gender matter? Gend. Dev. 2002, 10, 10-20. [CrossRef]

23. Geraldine, T. Climate Change and Gender Justice; Practical Action Publishing Ltd.: Warwickshire, UK, 2009.

24. Dankelman, I. Introduction: Exploring Gender, Environment and Climate Change. In Gender and Climate Change: An Introduction; Earthscan: London, UK, 2010; pp. 1-20.

25. McLaughlin, P.; Dietz, T. Structure, agency and environment: Toward an integrated perspective on vulnerability. Glob. Environ. Chang. 2008, 18, 111. [CrossRef]

26. Borquez, R. Resilience to climate change: From theory to practice through co- production of knowledge in Chile. Sustain. Sci. 2017, 12, 163-176. [CrossRef]

27. Boon, H.J.; Cottrell, A.; King, D.; Stevenson, R.B.; Millar, J. Bronfenbrenner's bioecological theory for modelling community resilience to natural disasters. Nat. Hazards 2012, 60, 381-408. [CrossRef]

28. Shakya, C.; Cooke, K.; Gupta, N.; Bull, Z. Building Institutional Capacity for Enhancing Resilience to Climate Change: An Operational Framework and Insights from Practice; Oxford Policy Management: Oxford, UK, 2018.

29. Atela, J.; Gannon, K.E.; Crick, F. Climate Change Adaptation among Female-Led Micro, Small, and Medium Enterprises in Semiarid Areas: A Case Study from Kenya; PRISE: London, UK, 2018.

30. Bours, D.; Pringle, P. Guidance Note 3: Theory of Change Approach to Climate Change Adaptation Programming; SEA Change CoP and UKCIP: Oxford, UK, 2014.

31. Steinbach, D.; Kaur, N.; Manuel, C.; Saigal, S. Building Resilience to Climate Change MGNREGS, Drought and Flooding in Odisha; IIED: London, UK, 2017.

32. Johnson, N.L.; Kovarik, C.; Meinzen-Dick, R.; Njuki, J.; Quisumbing, A. Gender, Assets, and Agricultural Development: Lessons from Eight Projects. World Dev. 2016, 83, 295-311. [CrossRef]

33. Parry, J.; Zamudio, J.; Echeverria, N.A. Climate Risk Management for Malaria Control in Kenya: The Case of The Western Highlands; UN Plaza: New York, NY, USA, 2013.

34. Chambers, R.; Conway, G.R. Sustainable Rural Livelihoods Practical Concepts for the 21st Century; Institute of Development Studies: Brighton, UK, 1991.

35. Olivier, D.W. The physical and social benefits of urban agriculture projects run by non-governmental organisations in Cape Town. Ph.D. Thesis, Stellenbosch University, Stellenbosch, South Africa, March 2015.

36. Goh, A. A Literature Review of the Gender-Differentiated Impacts of Climate Change in Developing Countries Structure; Food Policy Research Institute: Washington, DC, USA, 2012; No. 106.

37. Morse, S.; McNamara, N. Sustainable Livelihood Approach: A Critique of Theory and Practice; Springer Science \& Business Media: Dordrecht, The Netherlands, 2013.

38. Scoones, I. Livelihoods perspectives and rural development. J. Peasant Stud. 2009, 36, 171-196. [CrossRef]

39. Albore, A. Review on Determinants of Sustainable Rural Livelihood Diversification of Small Holder Farmers in Ethiopia. Int. J. Adv. Res. 2018, 6, 2320-5407. [CrossRef]

40. Nel, H. An integration of the livelihoods and asset-based community development approaches: A South African case study. Dev. South. Afr. 2015, 32, 511-525. [CrossRef]

41. Mendelberg, T.; Karpowitz, C.F. Women's authority in political decision-making groups. Leadersh. Q. 2016, 27, 487-503. [CrossRef]

42. Paul, M.J.C.; Weinthal, E.; Bellemare, M. Social Capital, Trust, and Adaptation to Climate Change: Evidence from Rural Ethiopia. Glob. Environ. Chang. 2016, 36, 124-138. [CrossRef]

43. Bett, B.; Kiunga, P.; Gachohi, J.; Sindato, C.; Mbotha, D.; Robinson, T.; Lindahl, J.; Gracea, D. Effects of climate change on the occurrence and distribution of livestock diseases. Prev. Vet. Med. 2017, 137, 119-129. [CrossRef] [PubMed]

44. Ngigi, M.W.; Mueller, U.; Birner, R. Gender differences in climate change adaptation strategies and participation in group-based approaches: An intra-household analysis from rural Kenya. Ecol. Econ. 2017, 138, 99-108. [CrossRef]

45. Bizimana, J.-C.; Regents, D.A.B.; Angerer, J.P. The 2010-2011 Drought Impacts on Cattle Market Integration in the Horn of Africa: A preliminary Evaluation using VAR and Structural Break Analysis. Selected Paper Prepared for Presentation at the Southern Agricultural Economics Association's 2016 Annual Meeting, San Antonio, TX, USA, 6-9 February 2016; pp. 1-26.

46. Mousavi, S.R.; Eskandari, H. A General Overview on Intercropping and Its Advantages in Sustainable Agriculture. J. Appl. Environ. Biol. Sci. 2011, 1, 482-486. 
47. Dulal, H.B.; Brodnig, G.; Onoriose, C.G.; Thakur, H.K. Capitalizing on Assets: Vulnerability and Adaptation to Climate Change in Nepal Capitalizing on Assets: Vulnerability and Adaptation to Climate Change in Nepal; The World Bank: Washington, DC, USA, 2010; No. 121.

48. Government of Kenya. National Climate Change Action Plan 2013-2017; Ministry of Environment and Forestry: Nairobi, Kenya, 2017.

49. Nelson, V.; Stathers, T. Resilience, power, culture, and climate: A case study from semi-arid Tanzania, and new research directions. Gend. Dev. 2009, 17, 81-94. [CrossRef]

50. Aguirre, B.E. Institutional Resilience and Disaster Planning for New Hazards: Insights from Hospitals. J. Homel. Secur. Emerg. Manag. 2017, 2, 1-20. [CrossRef]

51. Republic of Kenya. The Constitution of Kenya, 2010; National Council for Law Reporting: Nairobi, Kenya, 2010 ; p. 191. 